\title{
INFLUENCE OF ETHYL ALCOHOL ON ACCURACY OF TIME SINCE DEATH ESTIMATION BY THE METHOD OF AVTOFLUORESCENT LASER POLYARIMETRY OF POLYCRISTALLINE FILMS OF CEREBROSPINAL FLUID
}

\author{
CGarazdiuk M.S. ${ }^{1}$, Bachynskyi V.T. ${ }^{1}$, Garazdiuk O.I. ${ }^{2}$, Ivaskevich I.B. ${ }^{1}$ \\ Higher State Educational Establishment of Ukraine \\ «Bukovinian State Medical University», ${ }^{1}$ Department of Forensic Medicine and \\ Medical Law ${ }^{2}$ Department of Internal Medicine and Infectious Diseases \\ email: sudmed@bsmu.edu.ua
}

\begin{abstract}
Due to the high prevalence of death on the base of alcoholic intoxication of varying degrees, it is expedient to analyze the possibility of the influence of alcohol on the change in the structure of the polycrystalline films of the cerebrospinal fluid, and accordingly on the accuracy of the diagnosis of the time since death by the method of autofluorescent laser polarimetry.

The purpose of the work. To study the possible influence of alcohol and to develop objective forensic criteria for diagnosing its effects on the basis of analysis of changes in the polycrystalline structure of cerebrospinal fluid (CSF) films.

Materials and methods. Object of research: native films of CSF, selected in 80 corpses, in the quantity of 155 samples - 1 group; CSF from 30 healthy volunteers (group 0) - 30 samples; CSF films obtained in the deceased with the presence of ethyl alcohol in the blood, 30 samples - group 2. The methods of gas-liquid chromatography, laser-induced fluorescence and statistical processing of the results were used.

Results. The efficiency of using the methods of laser autofluorescence of polycrystalline films of the cerebrospinal fluid for the diagnosis of the time since death was proved. A statistically significant difference between cases of death from cardiovascular pathology with the presence and absence of ethyl alcohol in the organism was established by determining the magnitude of the statistical moment of the 4th order, which characterizes distribution of azimuth polarization values of microscopic images of laser-induced fluorescence. On this basis, an excellent balanced accuracy of the differentiation of the presence of ethyl alcohol in the human body (Ac (M4) $=94 \%$ ) was achieved.

Conclusion. Ethyl alcohol affects the structure of the polycrystalline films of the cerebrospinal fluid, which must be taken into account when estimating the time since death by autofluorescence laser polarimetric methods.

Key words: time since death, cerebrospinal fluid, ethyl alcohol, laser polarimetry, autofluorescence.

Introduction. Time since death (TSD) estimation is one of the key and for the time being still unresolved problems of forensic medicine practice. The exact setting of the time of death allows to exclude or confirm the involvement of one or another person in committing an offense, limit or expand the circle of suspects, verify the accuracy of the testimony of witnesses [1,2].

The definition of TSD is also complicated by the fact that a significant number of exogenous and endogenous factors, such as environmental conditions, the cause of death, anthropological features and the age of a person, are affected by posthumous processes occurring in the tissues of the corpse, etc. Recently, researchers began to pay attention to the impact of alcohol intoxication on the rate of flow of life processes and posthumous changes in human tissues [2].

It was observed that in the presence of alcohol in the blood of the corpses in cases of death of traumatic genesis the rosette-forming ability of lymphocytes in the posthumous period disappears earlier than in the absence of it and depends on the concentration of alcohol in the blood [3]. It was found that at concentrations of alcohol in the blood of 2,1-3, $0^{\circ}{ }_{00}$ during 6-72 hours after the death rosette-forming ability of the T-general lymphocyte increases, and at a concentration of $3-5 \%$ it decreases. A similar nature of the change was observed for the rosette-forming ability of B-lymphocytes.

Vavilov A.Yu. [4] noticed an increase in the overall thermal conductivity of the brain and liver in death on the background of blood loss, poisoning with ethyl alcohol, mechanical asphyxia. By studying supraviral zine reaction for the diagnosis of TSD Gladkikh D.B found that its results can not be evaluated in cases where at the time of death the person was in a state of intoxication [5].

Since laser polarimetric methods are effective for the diagnosis of TSD with high accuracy $[1,6,7]$, since they provide
\end{abstract}


new information on the morphological and optic-anisotropic structure of biological objects, which makes it possible to establish a connection between their physiological state and polarization -phase parameters of the images of their architectonics [6], that is why it is advisable to assume their sensitivity and to detect alcohol in the cerebrospinal fluid (CSF) of deceased persons.

The purpose of the work. To study the possible influence of alcohol and to develop objective forensic criteria for diagnosing its effects on the basis of analysis of changes in the polycrystalline structure of CSF films.

Material and methods of research. The methods of gas-liquid chromatography, laser-induced fluorescence (measurement of coordinate distributions of intensity and azimuth polarization of microscopic images of autofluorescence of polycrystalline films (PCF) of CSF), statistical processing of results were used.

As research objects in work were used 3 groups:

group 1 - native preparations of CSF films, selected from 80 corpses of both sexes (the main group of study), who died of pathology of the circulatory system in the age of 33 to 89 years, with a previosly known time of death, ranging from 1 to 26 hours - 155 specimens (some CSF semples was re-selected at different TSD intervals);

group 2 - posthumous polycrystalline planar films of CSF, obtained from persons that have died from the pathol- ogy of blood circulatory system with the presence of ethanol in the blood - 30 samples;

group 0 - 30 healthy volunteers - 30 samples.

The sampling was performed by the method of subccipital puncture from a large occipital cistern in corpses and at spinal anesthesia in the preparation for surgical interventions in healthy volunteers [8].

Concentration of ethyl alcohol in blood was determined during the forensic medical examination of corpses in the department of forensic medical toxicology of the CMI "Regional Bureau of Forensic Medical Examination" of the Department of Healthcare of Chernivtsi Regional State Administration through gas-liquid chromatography on the device "Crystal-2000M".

PCF of CSF were formed in identical conditions by applying a drop at room temperature $(\mathrm{t}=220 \mathrm{C})$ to an optically homogeneous glass.

Measurement of coordinate distributions (two-dimensional arrays of values in the plane of PCF of CSF) of the azimuth values and the ellipticity of polarization at the points of the microscopic images was performed in the location of the fluorescence laser stokes polarimeter (Fig. 1), developed by the scientists of the Chernivtsi National University named after Yuriy Fedkovich [6]:

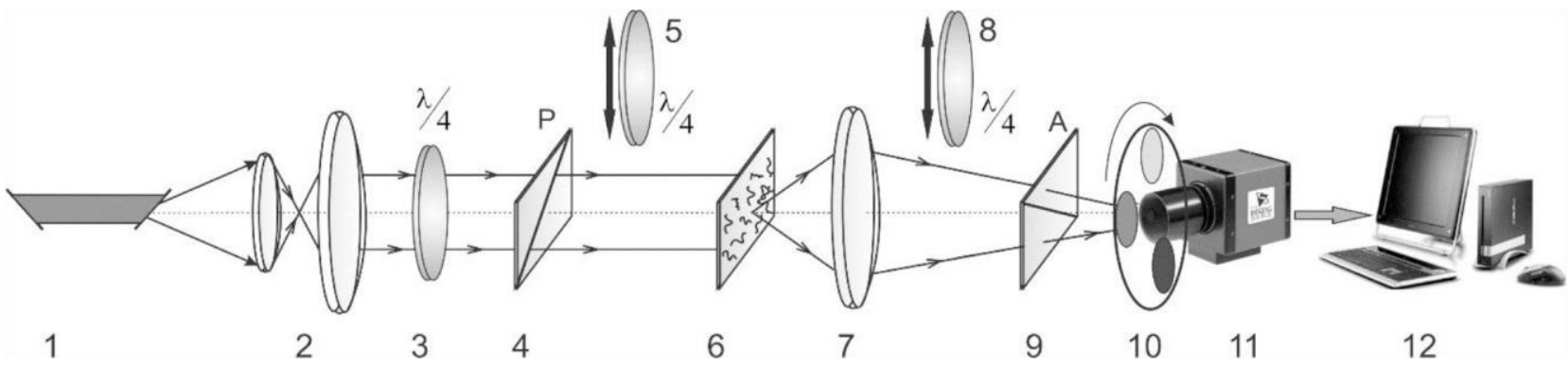

Fig. 1. Optical circuit of autofluorescence Stokes polarimeter. The explanation in the text

PCF of CSF 6 irradiations regime consisted of parallel $\left(\varnothing=2 \times 10^{3} \mu \mathrm{m}\right)$ bunch of «blue» $\left(\lambda_{2=}=0.405 \mu \mathrm{m}\right)$ semiconductor laser 1. Polarization irradiator consists of two polarization elements - quarter-wave plate 3 and polarizator 4. Image 6 PFL samples using polarization object glass 7 (Nikon CFI Achromat P, the focal length - 30mm, aperture - 0.1, magnification - 4x) was projected into the light-sensitive plane 10 of CCD-camera (The Imaging Source DMK 41AU02. AS, monochrome $1 / 2$ «CCD, Sony ICX205AL (progressive scan); resolution - 1280x960; photosensitive plane size - 7600x6200 $\mu \mathrm{m}$; sensitivity - $0.05 \mathrm{~lx}$; dynamic range - 8 bit). PCF of CSF 6 samples polarization analysis was carry out by the help of quarter- wave plate 8 and polarizator 9 .

To excite autofluorescence, the «blue» semiconductor laser LSR405ML-LSR-PS-II with a wavelength of $0.405 \mu \mathrm{m}$ and a power of $50 \mathrm{~mW}$ was used in the position of a standard stokes polarimeter.

The main information objects for the given scheme are a set of:

1) directly measured distributions of the auto-fluorescence intensity of the PCF of CSF;

2) azimuth polarization of the laser-induced fluorescence of the PCF of CSF.

A detailed description of the calculations is given in the sources [6,7]. The main analytical tool for estimating the distributions of the intensity values and the fluorescence polarization azimuths of the PCF of CSF was the statistical moments of the first, second, third and fourth orders, which were calculated by algorithms [6] and characterize the mean value $\left(\mathrm{Z}_{1}\right)$, dispersion $\left(Z_{2}\right)$, asymmetry $\left(Z_{3}\right)$ and excess $\left(Z_{4}\right)$ of such distributions.

\section{Results and discussion.}

Initially, the concentration of ethyl alcohol was established according to the forensic toxicological study in the blood of the deceased 2 nd group, which was $1,71 \pm 0,870 / 00$.

The next step was to study the possibilities of laser-induced autofluorescence microscopy in the developed forensic 
medical criteria for the study of the effect of ethyl alcohol on the time since death estimation from cardiovascular pathology using statistical analysis of intensity distributions and azimuths of polarization of microscopic fluorescence images of PCF of CSF in different spectral regions of optical radiation.

Forensic criteria for a good level of balanced accuracy were found to study the effect of ethyl alcohol on time since death by spectrally selective mapping of the intensity of the laser-induced autofluorescence of the PCF of CSF from group 1 and group 2. It is statistical moments of the 4th order characterizing the intensity distributions fluorescence in the «green-yellow» and «red» spectral regions with Ac (M4) = 800/0 -900/0 (see Tab. 1).

Table 1

Statistical moments of the 1st to 4th orders characterizing the distribution of the intensity of the autofluorescence of the polycrystalline films of the cerebrospinal fluid in the «red» region of the spectrum

\begin{tabular}{|l|l|l|l|}
\hline \multirow{2}{*}{$\begin{array}{l}\text { Statistical } \\
\text { moments }\end{array}$} & $\begin{array}{l}\text { Control group } \\
\text { healthy volunteers } \\
(\mathrm{n}=30)\end{array}$ & $\begin{array}{l}\text { The cause of death } \\
\text { pathology of the } \\
\text { circulatory system } \\
(\mathrm{n}=30)\end{array}$ & $\begin{array}{l}\text { alcohol } \\
\text { poisoning }(\mathrm{n}=30)\end{array}$ \\
\hline Mean value, $M_{1}$ & $0,39 \pm 0,021$ & $0,11 \pm 0,006$ & $0,19 \pm 0,011$ \\
\hline $\mathrm{p}_{1}$ & & $p \prec 0,05$ & $p \prec 0,05$ \\
\hline $\mathrm{P}_{2}$ & & $p \prec 0,05$ \\
\hline Dispersion, $M_{2}$ & $0,19 \pm 0,012$ & $0,11 \pm 0,006$ & $0,14 \pm 0,008$ \\
\hline $\mathrm{p}_{1}$ & & $p \prec 0,05$ & $p \prec 0,05$ \\
\hline $\mathrm{P}_{2}$ & & $p \prec 0,05$ & \multicolumn{2}{|l|}{} \\
\hline Asymmetry, $M_{3}$ & $0,68 \pm 0,037$ & $0,99 \pm 0,053$ & $1,31 \pm 0,071$ \\
\hline $\mathrm{P}_{1}$ & & $p \prec 0,05$ & $p \prec 0,05$ \\
\hline $\mathrm{P}_{2}$ & & $p \prec 0,05$ & $1,09 \pm 0,063$ \\
\hline Excess, $M_{4}$ & $0,83 \pm 0,044$ & $1,53 \pm 0,084$ & $p \prec 0,05$ \\
\hline $\mathrm{p}_{1}$ & & $p \prec 0,05$ \\
\hline $\mathrm{P}_{2}$ & & $p \prec 0,05$ \\
\hline
\end{tabular}

For other statistical moments balanced accuracy also increases to a satisfactory level $\mathrm{Ac}\left(\mathrm{M}_{1,2,3,4}\right)=75 \%-87 \%$. Having investigated the statistical distributions of fluorescence azimuths, it was discovered that it is possible to achieve an excellent level of balanced accuracy on the example of the statistical moment of the 4th order, which characterizes the distributions of fluorescence azimuths in the «red» spectral region $A c\left(M_{4}\right)=95 \%$. For other statistical moments, the balanced accuracy of differentiation of death due to cardiovascular pathology in the presence of ethyl alcohol in the blood also rises to a good level $A c\left(M_{1 ; 2 ; 3 ; 4}\right) \leq 90 \%$

The revealed differences in the structure of PCF od CSF can be explained by the influence of ethyl alcohol on the formation of a polycrystalline film network. Probably, ethyl alcohol, penetrating through the blood-brain barrier, affects both the quantitative composition of the mediumsmolecular compounds, as indicated by Witer et al. [9,10], as well as on the structure of certain proteins, in particular gamma-aminobutyric acid receptors, and, thus, affects the tertiary and quaternary structure of CSF proteins [11], which is reflected in the analysis of the PCF od CSF. The obtained data prove certain influence of ethyl alcohol on the structure of PCF od CSF and allow to recommend a new methodological approach for the determination of TSD in the presence of ethyl alcohol in the blood.

\section{Conclusions}

1. The possibilities of forensic medical objective differentiation of the estimation of the influence of ethyl alcohol on the course of post-mortem processes in case of cardiovascular pathology by the method of autofluorescence microscopy of polycrystalline films of the cerebrospinal fluid were analyzed.

2. Relationships between intensity distributions and azimuths of the fluorescence polarization of the polycrystalline films of the cerebrospinal fluid of the deceased due to the pathology of the circulatory system and severe alcohol intoxication with the possible fatal outcome and the magnitude and range of changes in the statistical moments of the 1st to 4 th orders characterizing such autofluorescence images were investigated.

3.A good level of balanced precision of the differentiation of the causes of death in the «red» area of the spectrum has been achieved $A c\left(M_{1,2 ; 3 ; 4}\right) \leq 90 \%$. At the same time, the value of the balanced accuracy of differentiation in the case of 
weak alcohol poisoning is significantly lower (by 10-15\%) and practically does not reach the satisfactory level (Ac<75\%) except for the «red» area of the spectrum (Ac $\sim 80 \%)$.

\section{Список літератури:}

1. Ushenko OG, Sidor MI, Garazdiuk M, Gritsiuk MV, Sobko OV. Azimuthally stable laser polarimetry of polycrystalline films of human biological fluids. Proc. SPIE 9216, Optics and Photonics for Information Processing VIII, 92161C [Internet]. 2014 Sept 19 [cited 2017 Dec 23]. Доступно: https://www.spiedigitallibrary.org/conference-proceedings-ofspie/9216/1/Azimuthally-stable-laser-polarimetry-of-polycrystalline-films-of-humanbiological/10.1117/12.2061097.short doi: https://doi.org/10.1117/12.2061097

2. Гуров ОМ, Кондратенко ВЛ, Бурчинський ВГ, Гладких ДБ. Сучасний алгоритм судово-медичної діагностики давності настання смерті у ранній постмортальний період. Київ; 2017. 36 с.

3. Дунаєв ОВ. Вплив алкоголю на динаміку імунних показників крові померлих від ішемічної хвороби серця (IXC) при встановленні давності настання смерті. Український судово-медичний вісник. 2000;(1):36-8.

4. Вавилов АЮ. Судебно-медицинская диагностика давности смерти тепловыми методами [дисертація]. Москва; 2009. $377 \mathrm{c}$.

5. Гладких Д.Б. Судово-медична діагностика давності настання смерті за суправітальною реакцією зіниць [автореферат]. Київ: НМАПО ім. П.Л. Шупика; 2015. 19 с.

6. Ушенко ОГ, Пішак ВП, Ангельський ОВ, Ушенко ЮО. Лазерна поляризаційна морфологія біологічних тканин: статистичний і фрактальний підходи. Чернівці: Колір-Друк; 2007. 341 с.

7. Bachynskyi V, Garazdiuk M, Vanchuliak O, Bezhenar I, Garazdiuk O. Post mortem interval estimation: features of cerebrospinal fluid films autofluorescent laser polarimetry. Fol Soc Med Leg Slov. 2016;6(2):67-72.

8. Марданлы СГ, Первушин ЮВ, Иванова ВН. Спинномозговая жидкость, лабораторные методы исследования и их клинико-диагностическое значение. Электрогорск: ЭКОлаб; 2011.72 с.

9. Витер ВИ, Коротун ВН, Лесников ВВ, Наумова НА, Поздеев АР. Оценка концентрации этанола в тканях и биологических жидкостях трупов при отсроченном судебно-химическом исследовании. Судебная экспертиза. 2012;1:121-5.

10. Витер ВИ, Ермаков АВ. Результаты исследования посмертных изменений уровня среднемолекулярных соединений в спинномозговой жидкости лиц, умерших от болезней системы кровообращения. Проблемы экспертизы в медицине. 2005;5:27-8.

11. Табакофф Б, Хоффман ПЛ. Нейробиологические эффекты алкоголя. Вопросы наркологии. 2003;5:27-42.

\section{References:}

1. Ushenko OG, Sidor MI, Garazdiuk M, Gritsiuk MV, Sobko OV. Azimuthally stable laser polarimetry of polycrystalline films of human biological fluids. Proc. SPIE 9216, Optics and Photonics for Information Processing VIII, 92161C [Internet]. 2014 Sept 19 [cited 2017 Dec 23]. Available from: https://www.spiedigitallibrary.org/conferenceproceedings-of-spie/9216/1/Azimuthally-stable-laser-polarimetry-of-polycrystalline-films-of-human-

biological/10.1117/12.2061097.short doi: https://doi.org/10.1117/12.2061097

2. Hurov OM, Kondratenko VL, Burchyns'kyi VH, Hladkykh DB. Suchasnyi alhorytm sudovo-medychnoi diahnostyky davnosti nastannia smerti u rannii postmortal'nyi period [The modern algorithm of forensic diagnostics of prescription of an onset of death in the early post-mortem period]. Kyiv; 2017. 36 s. (in Ukrainian)

3. Dunaiev OV. Vplyv alkoholiu na dynamiku imunnykh pokaznykiv krovi pomerlykh vid ishemichnoi khvoroby sertsia (IKhS) pry vstanovlenni davnosti nastannia smerti [Effect of Alcohol on the Dynamics of Immune Blood Indices of Deaths of Ischemic Heart Disease (IHD) in Establishing the Limitation of Death]. Ukrains'kyi sudovo-medychnyi visnyk. 2000;(1):36-8. (in Ukrainian)

4. Vavilov AYu. Sudebno-meditsinskaya diagnostika davnosti smerti teplovymi metodami [Forensic diagnosis of prescription of death by thermal methods] [dissertation]. Moskow; 2009. 377 s. (in Russian)

5. Hladkykh D.B. Sudovo-medychna diahnostyka davnosti nastannia smerti za supravital'noiu reaktsiieiu zinyts' [Forensic medical diagnostics of the time of death using supravital pupil reaction] [avtoreferat]. Kyiv: NMAPO im. P.L. Shupyka; 2015. 19 s. (in Ukrainian)

6. Ushenko OH, Pishak VP, Anhel's'kyi OV, Ushenko YuO. Lazerna poliaryzatsiina morfolohiia biolohichnykh tkanyn: statystychnyi i fraktal'nyi pidkhody [Laser polarization morphology of biological tissues: statistical and fractal approaches]. Chernivtsi: Kolir-Druk; 2007. 341 s. (in Ukrainian)

7. Bachynskyi V, Garazdiuk M, Vanchuliak O, Bezhenar I, Garazdiuk O. Post mortem interval estimation: features of cerebrospinal fluid films autofluorescent laser polarimetry. Fol Soc Med Leg Slov. 2016;6(2):67-72.

8. Mardanly SG, Pervushin YuV, Ivanova VN. Spinnomozgovaya zhidkost', laboratornye metody issledovaniya i ikh klinikodiagnosticheskoe znachenie [Cerebrospinal fluid, laboratory research methods and their clinical diagnostic value]. Elektrogorsk: EKOlab; 2011. 72 s. (in Russian)

9. Viter VI, Korotun VN, Lesnikov VV, Naumova NA, Pozdeev AR. Otsenka kontsentratsii etanola v tkanyakh i 
biologicheskikh zhidkostyakh trupov pri otsrochennom sudebno-khimicheskom issledovanii [Assessment of ethanol concentration in tissues and biological liquids of corpses in case of suspended forensic chemical examination]. Sudebnaya ekspertiza. 2012;1:121-5. (in Russian)

10. Viter VI, Ermakov AV. Rezul'taty issledovaniya posmertnykh izmeneniy urovnya srednemolekulyarnykh soedineniy $\mathrm{v}$ spinnomozgovoy zhidkosti lits, umershikh ot bolezney sistemy krovoobrashcheniya [The results of research median-mass substances levels in liquor of persons who was died from cardiovascular system diseases]. Problemy ekspertizy v meditsine. 2005;5:27-8. (in Russian)

11. Tabakoff B, Khoffman PL. Neyrobiologicheskie effekty alkogolya [Neurobiological effects of alcohol]. Voprosy narkologii. 2003;5:27-42. (in Russian)

\title{
ВПЛИВ ЕТИЛОВОГО СПИРТУ НА ТОЧНІСТЬ ВИЗНАЧЕННЯ ЧАСУ НАСТАННЯ СМЕРТІ МЕТОДОМ АВТОФЛУОРЕСЦЕНТНОЇ ЛАЗЕРНОЇ ПОЛЯРИМЕТРІЇ ПОЛІКРИСТАЛІЧНИХ ПЛІВОК СПИННОМОЗКОВОЇ РІДИНИ
}

\author{
Гараздюк М.С., Бачинський В.Т., Гараздюк О.І., Іваськевич І.Б.
}

\begin{abstract}
Анотація
У зв'язку із значною поширеністю настання смерті на фоні алкогольного сп'яніння різного ступеню, доцільним є про- аналізувати можливість впливу алкоголю на зміну структури полікристалічних плівок спинномозкової рідини, а відповідно і на точність діагностики давності настання смерті методом автофлуоресцентної лазерної поляриметрії.

Мета роботи. Вивчити можливий вплив алкоголю та розробити об’єктивні судово-медичні критерії діагностики його впливу на основі аналізу зміни полікристалічної структури плівок СМР.

Матеріали і методи. Об'єкт дослідження: нативні препарати плівок СМР, відібрані у 80 трупів, у кількості 155 зразків - 1 група; СМР від 30 здорових добровольців (група 0) - 30 зразків; плівки СМР, одержані у померлих 3 наявністю етилового спирту в крові, 30 зразків - група 2. У роботі використовували методи газово-рідинної хроматографії, лазерно-індукованої флуоресценції та статистичної обробки результатів.

Результати. Було доведено ефективність використання методів лазерної автофлуоресценції полікристалічних плівок спинномозкової рідини для діагностики давності настання смерті та встановлена статистично достовірна різниця між випадками смерті від серцево-судинної патології при наявності та за відсутності етилового спирту в організмі шляхом визначення величини статистичного моменту 4-го порядку, який характеризує розподіли величини азимута поляризації мікроскопічних зображень лазерно-індукованої флуоресценції. На цій основі було досягнуто відмінної збалансованої точності диференціації наявності етилового спирту в організмі людини $\left(\mathrm{A}_{\mathrm{C}}\left(\mathrm{M}_{4}\right)=94 \%\right)$.

Висновок. Етиловий алкоголь впливає на структуру полікристалічних плівок спинномозкової рідини, що необхідно враховувати при визначенні давності настання смерті автофлуоресцентними лазерними поляриметричними методами.

Ключові слова: давність настання смерті, спинномозкова рідина, етиловий спирт, лазерна поляриметрія, автофлуо- ресценція.

\section{ВЛИЯНИЕ ЭТИЛОВОГО СПИРТА НА ТОЧНОСТЬ ОПРЕДЕЛЕНИЯ ВРЕМЕНИ НАСТУПЛЕНИЯ СМЕРТИ МЕТОДОМ АВТОФЛУОРЕСЦЕНТНОЙ ЛАЗЕРНОЙ ПОЛЯРИМЕТРИИ ПОЛИКРИСТАЛЛИЧЕСКИХ ПЛЕНОК СПИННОМОЗГОВОЙ ЖИДКОСТИ}

\author{
Гараздюк М.С., Бачинский В.Т., Гараздюк А.И., Иваськевич И.Б.
}

\section{Аннотация}

В связи с широкой распространенностью наступления смерти на фоне алкогольного опьянения различной степени, целесообразно проанализировать возможность влияния алкоголя на изменение структуры поликристаллических пленок спин- номозговой жидкости, а соответственно и на точность диагностики давности наступления смерти методом автофлуоресцент- нои лазерной поляриметрии.

Цель работы. Изучить возможное влияние алкоголя и разработать объективные судебно-медицинские критерии диагностики его воздействия на основе анализа изменения поликристаллического структуры пленок CMP. 
Материалы и методы. Объект исследования: нативные препараты пленок СМР, отобранные в 80 трупов, в количестве 155 образцов - 1 группа; СМР от 30 здоровых добровольцев (группа 0) - 30 образцов; пленки СМР, полученные у умерших с наличием этилового спирта в крови, 30 образцов - группа 2. В работе использовали методы газово-жидкостной хроматографии, лазерно-индуцированной флуоресценции и статистической обработки результатов.

Результаты работы. Авторами была доказана эффективность использования методов лазерной автофлуоресценции поликристаллических пленок спинномозговой жидкости для диагностики давности наступления смерти и установлена статистически достоверная разница между случаями смерти от сердечнососудистой патологии при наличии и при отсутствии этилового спирта в организме путем определения величины статистического момента 4-го порядка, который характеризует распределения величины азимута поляризации микроскопических изображений лазерно-индуцированной флуоресценции. На этой основе была достигнута отличная сбалансированная точность дифференциации наличия этилового спирта в организме человека $(\mathrm{Ac}(\mathrm{M} 4)=94 \%)$.

Вывод. Этиловый алкоголь влияет на структуру поликристаллических пленок спинномозговой жидкости, что необходимо учитывать при определении давности наступления смерти автофлуоресцентнимы лазерными поляриметрическими методами.

Ключевые слова: давность наступления смерти, спинномозговая жидкость, этиловый спирт, лазерная поляриметрия, автофлуоресценция.

УДК: 340.6:617.747-073.55-091

\section{МОЖЛИВОСТІ БАГАТОВИМІРНОЇ ПОЛЯРИЗАЦЙНОЇ ТА АВТОФЛУОРЕСЦЕНТНОЇ МІКРОСКОПЇ̈ БІОЛОГІЧНИХ ТКАНИН ТА РІДКИХ СЕРЕДОВИЩ ОРГАНІЗМУ ЛЮДИНИ ДЛЯ ДІАГНОСТИКИ ДАВНОСТІ НАСТАННЯ СМЕРТІ \\ ССаркісова Ю.В., Бачинський В.Т., Паливода О.Г. \\ ВДНЗУ «Буковинський державний медичний університет»}

Резюме. В статті проаналізовано сучасну наукову літературу з питань можливостей застосування лазерних поляриме- тричних методів дослідження біологічних тканин та середовищорганізму людини для встановлення давності настання смерті в процесі судово-медичного дослідження.

Дане питання є дуже актуальним, адже практично кожна ділянка кримінального процесу, так чи інакше, стикається з необхідністю проведення якої-небудь експертизи для внесення ясності в обставини справи. У зв'язку з цим, вирішальне зна- чення набуває питання про постійне вдосконалення чинного механізму проведення і реалізації результатів судово-медичної експертизи в кримінальному процесі.

У циклі проаналізованих в огляді робіт, розроблені основи лазерної поляриметричної діагностики посмертних і пато- логічних змін архітектоніки структурованих біологічних тканин та середовищ організму людини. Відібрані для дослідження об’єкти об’єднують спільні оптичні властивості їх архітектоніки - просторові сітки утворені кристалічними доменами, речо- вина яких володіє властивостями оптичних кристалів.

Встановлені попередні позитивні результати підштовхують до подальшого пошуку точок прикладання лазерних поля- риметричних методів для потреб судово-медичної практики, зокрема встановлення давності настання смерті.

Так метою роботи є розробка комплексу судово-медичних критеріїв для удосконалення точності встановлення дав- ності настання смерті шляхом використання спектру методів багатомірної поляризаційної та автофлуоресцентної мікроско- пії скловидного тіла ока людини.

У практичному плані можна очікувати, що поляризаційні методи дозволять отримати нову інформацію про морфоло- гічну та оптико-анізотропну структуру біотканин. Тому, актуальним є пошук взаємозв'язків між фізіологічним станом біотка- нин і поляризаційно-фазовими параметрами їх зображень і архітектоніки.

Ключові слова. Лазер, судова медицина, давність настання смерті.

ВСТУП. Лейтмотивом сучасного стану судово-медичної практики є невпинне зростання вимог до висновку судово-медичного експертазадля підвищення рівня розслідування злочинів, як джерела доказів у справі. Відповідно найактуальнішим завданням судово-медичної експертизи в даний час є отримання максимально можливої та точної інформації про об’єкт при його дослідженні. Саме тому застосування нових технологій у судово-медичнійекспертній діяльності стає невід'ємною частиною технологічного забезпечення відділень. Однак, значна частина методик, що застосовуються на практиці у наш час, попри свою достатню інформативність, у ряді випадків не дають можливості достовірно та точно відповісти на поставлені експертом питання. Серед кола проблем, слід відзначити низьку лабораторну відтворюваність, мінливість, а також вплив людського фактору на отримання результатів, оскількидля правильного їх застосування експерт повинен володіти спеціальними знаннями та мати достатній практичний досвід $[3]$. 